\title{
Consumers' decision-making style as a basis for market segmentation
}

Received (in revised form): 20th September, 2001

\section{Dr Gianfranco Walsh}

is an Assistant Professor of Marketing at the University of Hanover's Department of Marketing II, Germany. His research focuses on cross-cultural consumer research, e-commerce and movie marketing. Gianfranco's work has been published in the Journal of Consumer Affairs, Academy of Marketing Science Review and several German journals. He also works closely with several organisations in the retailing and Internet sector as a consultant.

\section{Thorsten Hennig-Thurau}

is an Assistant Professor in the Department of Marketing at the University of Hanover, Germany. His research interests include relationship marketing, services management and the management of higher education. Dr Hennig-Thurau's work has been published in, among others, Psychology \& Marketing, Journal of Marketing Management and Journal of Service Research. In addition to his academic activities, he is also an experienced marketing consultant and marketing researcher.

\section{Vincent Wayne-Mitchell}

is Professor of Marketing, Manchester School of Management, UMIST. His research focuses on consumer decision making and complaining behaviour. He has done work for numerous private and public organisations including: Coca-Cola, Safeway, Tesco, Cooperative Bank, EU and DTI.

\section{Klaus-Peter Wiedmann}

is Chair of the Department of Marketing II at Hanover University, Germany. His research focuses on strategic marketing, corporate identity, and corporate reputation. Klaus-Peter Wiedmann is Country Director (Germany) of the Reputation Institute.

Gianfranco Walsh Department of Marketing II, University of Hanover, Koenigsworther Platz 1, 30167 Hannover, Germany.

Tel: (+49) 511762 4540; Fax: (+49) 511762 3142; e-mail:

walsh@m2.uni-hannover.de

\begin{abstract}
Decision-making styles are important to marketing because they determine consumer behaviour, are relatively stable over time and thus are relevant for market segmentation. The need to test the generalisability of Sproles and Kendall's ${ }^{1}$ consumer styles inventory (CSI) in different countries and an attempt to extend the original work led the authors to test the structure of decision-making styles of German shoppers and its use in segmenting consumers. From a sample of 455 German consumers, a seven-dimensional structure of decision-making styles was found using principal components analysis and confirmatory factor analysis. Cluster analysis identified six meaningful and distinct decision-making groups. These decision-making groups can be viewed as basic segments that can be used in conjunction with traditional market segmentation approaches. Implications for marketing research and practitioners are discussed.

Understanding buying-related decision-making behaviour of consumers is important for companies' strategic marketing activities and effective communication with different consumer segments is helped by understanding psychological constructs which relate to

consumer behaviour, eg personality, ${ }^{2}$ attitude $^{3}$ or lifestyle. ${ }^{4}$ One approach to categorising consumer behaviour is to identify decision-making typologies. Such typologies aim to attribute certain decision-making traits to consumers in order to classify them as economic, ${ }^{5}$
\end{abstract}


Table 1: Descriptions of consumer decision-making dimensions

Perfectionism: This trait is characterised by a consumer's search for the highest or very best quality in products. Respondents scoring high on this dimension could be expected to be careful, systematic or comparison shoppers.

Brand consciousness: Consumers who are oriented towards buying the more expensive, well-known national brands, believing that a higher price means better quality. They also prefer best-selling, advertised brands.

Novelty-fashion consciousness: This dimension characterises novelty seekers, who find seeking out new things pleasurable. Novelty seekers are likely to shop less carefully and more impulsively, and are less price sensitive.

Recreational shopping consciousness: Consumers who view shopping as recreation and entertainment. These consumers find shopping a pleasant activity and shop just for the fun of it.

Price-value consciousness: Those scoring high on this dimension look for sale prices, appear conscious of lower prices in general, and are likely to be comparison shoppers. They are also concerned with getting the best value for their money.

Impulsiveness, carelessness: The impulsiveness dimension measures an orientation that is characterised by careless and impulsive shopping. Those scoring high on this dimension do not plan their shopping and appear unconcerned about how much they spend.

Confused by overchoice: This trait characterises consumers who are confused about the quality of different brands and by the information available. High scorers on this characteristic have difficulties making choices.

Brand-loyal, habitual: Consumers who have favourite brands and stores and have formed habits in choosing these repetitively.

apathetic, ${ }^{6}$ quality conscious, ${ }^{7}$ choosy, ${ }^{8}$ information seeking, ${ }^{9}$ price conscious, ${ }^{10}$ variety seeking ${ }^{11}$ or brand loyal. ${ }^{12}$

Despite its intuitive appeal, the latter approach can be criticised because it is doubtful that consumers can be grouped into distinct unidimensional behaviour typologies. Labelling a consumer always as either 'economic' or 'price conscious' is unrealistically simplistic and does not reflect the growing research into the so-called 'hybrid consumer'. ${ }^{13}$ Consumers are rarely exclusively fashion or price conscious, but tend to make buying decisions related to a specific buying situation. Therefore, for most consumers, several decision-making dimensions prevail. In addition, existing characterisations are based on separate theoretical concepts and consequently only capture certain aspects of consumer decision-making behaviour. This means the existing decision-making typologies are often unrelated and their practical relevance is limited.

More recent approaches attempt to address and avoid these weaknesses by postulating a multidimensional understanding of consumer decision-making characteristics. In this context, the work by Sproles and Kendall, ${ }^{14}$ who developed a consumer styles inventory (CSI) is of particular interest. In their integrative approach, Sproles and Kendall assume that consumer decision-making behaviour can be explained by eight central decision-making dimensions that influence a consumer's decision-making behaviour through an individual combination of all eight dimensions. An important assumption of this approach is that individual decision-making dimensions vary from consumer to consumer and each consumer has a specific decision-making style. ${ }^{15}$ Although initially developed for US consumers, replications have been conducted in several countries, but have lacked wider generalisability because they have mainly used student samples. Furthermore, little research on the CSI has made the obvious extension to use the styles as a basis for market segmentation. ${ }^{16}$

The objective of this study was to examine the usefulness of the CSI for 
market segmentation using a non-student sample to improve the generalisability of the results. Accordingly, Sproles and Kendall's CSI is discussed in the context of existing approaches to market segmentation; its reliability and validity in Germany is tested with a sample of 455 consumers and an attempt is made to identify the existence of German consumer decision-making segments using cluster and multiple discriminant analysis.

\section{CONCEPTUAL BASIS: DECISION-MAKING STYLE AND MARKET SEGMENTATION}

\section{The concept of decision-making styles}

A consumer's decision-making style is defined as 'a mental orientation characterizing a consumer's approach to making choices', ${ }^{17}$ which, according to Sproles and Kendall, is relatively stable and has a lasting effect on consumer decision making. The theoretical assumption behind the concept is that consumers have eight different decision-making dimensions that determine their decision making. These eight dimensions originally identified in a literature review carried out by Sproles and Kendall (see Table 1) ${ }^{1}$ are measured in a questionnaire comprising 40 items rated on a five-point scale labelled 'strongly agree' (5) and 'strongly disagree' (1). The postulated eight-dimensional model was subjected to a principal component analysis and support for the anticipated dimensions found. ${ }^{19}$ The decision-making style concept implies a simultaneous relevance of several decision-making dimensions. The ability to determine individual consumer decision-making styles can be seen as a key characteristic of the concept. For example, it is possible to determine whether a consumer who shows a proclivity to impulsive buying is also likely to experience overload-confusion.

Despite the eight-dimensional structure being confirmed in the original study, ${ }^{20}$ there are indications that the eight-factor model does not represent an ideal solution because some dimensions showed a poor reliability (eg price-value consciousness and impulsiveness). ${ }^{21}$

Since marketing theories and concepts empirically tested in America may not be universally applicable, an uncritical application to other countries can lead to validity problems and to results of questionable worth to marketing. Hence, it is necessary to validate concepts and instruments in each country. Indeed, Sproles and Kendall ${ }^{22}$ requested that 'to establish generality further, [the CSI] must be administered to other populations'. Several authors have responded and replications have been carried out in South Korea, ${ }^{23} \mathrm{New}$ Zealand, ${ }^{24}$ Greece, the USA, India and New Zealand, ${ }^{25}$ Great Britain ${ }^{26}$ and China. ${ }^{27,28}$ The original structure of decision-making style, by and large, was confirmed in all seven countries. Some country-specific structures of decision-making styles emerged, however, eg in South Korea ${ }^{29}$ the dimension novelty-fashion consciousness could not be confirmed, but a new dimension time-energy conserving was found. ${ }^{30}$ Lysonski et al. ${ }^{31}$ furnished the most convincing evidence for country-specific differences (including translation-related difficulties in Greece and India) with their four-country study. Fan and Xiao tested a modified seven-factor model, which they did not consider an ideal representation of Chinese decision-making styles and because of the weak reliability of two dimensions, declared themselves in favour of a five-factor model. ${ }^{32}$

Further issues of generalisability to the general population exist with the CSI as 
the original study used US high-school students to establish the reliability and validity of the instrument. Finally, limitations exist with regard to the initial processing of the conceptualisation, in which only Cronbach's alpha and exploratory factor analysis were used. More powerful methods such as confirmatory factor analysis were not used.

\section{Decision-making styles as a tool for market segmentation}

Usually, two related aspects are described within the notion market segmentation. The first aspect describes the process of dividing a heterogeneous mass market into smaller, relatively homogeneous segments, which will respond differently to marketing mix elements, with the aim of selecting one or more segments on which to focus. This involves determining the price, distribution, product and communications decisions for each segment (eg service, content of advertisement).

From a methodological perspective, effective market segmentation requires meaningful bases or variables with which the total market can be divided.

Consumer markets are typically divided by demographic, psychographic or buying-related (ie behavioural) variables, which are used individually or in conjunction. A demographic segmentation can be conducted relatively easily because the necessary data tend to be available. It is, however, unsuitable for capturing differences in consumer preferences. Psychographic segmentation on the other hand is able to identify product preferences, but it cannot be easily related/assigned to marketing variables. For example, consumers with a certain lifestyle may not be reachable through conventional media. A more effective line of psychographic segmentation is the so-called 'benefit segmentation', ${ }^{33}$ which, in combination with conjoint analysis, tends to be very realistic and measurable; however, it is also not free of limitations. Behavioural segmentation is based on observable consumer behaviour; for example, media usage, store or brand choice. The strategic merit of the latter segmentation approach is limited because only past consumer behaviour is captured. The meaningfulness of such criteria, however, increases with the growing power of customer databases that are used in relationship marketing ${ }^{34}$ to group consumers into segments with varying attractiveness, depending on their respective customer value.

Overall, all available segmentation criteria have weaknesses and an ideal way of market segmentation is not achievable. Additional criteria will probably not lead to better market segmentation, but one way to increase the quality of market segmentation could be to develop a multistage segmentation approach. Using this approach, a consumer's decision-making style can be viewed as a preliminary or succeeding segmentation criterion that is used before/after a more differentiated segmentation through demographic, psychographic or behavioural criteria is conducted. ${ }^{35}$ Although decision-making styles groups could be of practical relevance per se, it is argued that they can be useful when used together with conventional segmentation criteria. By combining consumer decision-making style segments with traditional segmentation approaches, it is likely that the meaningfulness of the latter can be increased with regard to marketing decisions.

Suppose a beer manufacturer develops a new beer brand and is planning to introduce it using 'only' psychographic segmentation, from which several lifestyle groups emerge. Let us also suppose this 
manufacturer decides to target the lifestyle segment which shows the greatest fondness for the new brand. Marketers can usually relate shops to a certain lifestyle (group) and knowing where this group shops and spends its leisure time would certainly help in accurately targeting them. Such a psychographic approach, however, is perhaps not the most effective way to target consumers. Precise promotional activities would require a deeper understanding of consumer preferences at decision level. If this lifestyle group would be further segmented into decision-making groups and, for example, an 'impulsive' and 'quality

conscious/perfectionistic' group emerged, then marketers could carry out their targeting effort more precisely. For example, for the 'impulsive' group special displays and special merchandising techniques (in stores this lifestyle group is known to visit) could be used that stimulate impulse purchases (eg in-store promotions, provisional/temporary product shelving next to the checkouts) and the 'quality conscious/perfectionistic' group could be targeted with advertisements stressing the quality of the beer and its ingredients (eg Bavarian hops).

Sproles and Kendall argue that decision-making styles are stable over time, which for the above-mentioned criteria does only apply to a limited extent. A consumer's lifestyle, for example, changes more rapidly. ${ }^{36}$ Decision-making styles can be interpreted as basic buying-decision-making attitudes that consumers adhere to, even when they are applied to different goods, services or purchasing situations (eg perfectionism or a brand-switching tendency). Further, it is likely that certain basic needs and product preferences are associated with decision-making styles. A segment of perfectionistic, brand conscious and loyal consumers, for example, will go for solidly fabricated, branded, high-tier products.

So far, decision-making styles allow segmentation into different (basic) segments which can precede (or follow) other segmentation approaches. Brand manufacturers will have to evaluate the appropriateness of the different decision-making segments, that will be identified in this study, with regard to their own products. In conjunction with other numbers (eg customer turnover) basic segments can be selected that can then be analysed in depth using traditional segmentation approaches. On an elemental/basic level, strategic decisions can be supported. For instance, if a 'brand loyal, perfectionistic' segment is identified, a manufacturer of mobile phones can opt for a distribution through specialist shops. On this basis, it would seem appropriate for the manufacturer to then use traditional segmentation criteria as quasi second-order criteria (eg customers' preferences or benefits). The manufacturer of mobile phones could, for example, create subsegments based on the different preferences consumers have as to a mobile phone (eg size, long standby, small display). By doing so, it becomes possible to get a more refined picture of customer preferences and a better understanding of which subsegments exist. The approach described (see Figure 1) is also likely to enhance the development of products that fit the varying preferences of customers better than it would be without consumer decision-making style segments. A manufacturer of mobile phones, however, who knows that his (prospective) customers prefer a small display can still fail if the customers comprise a 'price conscious' and 


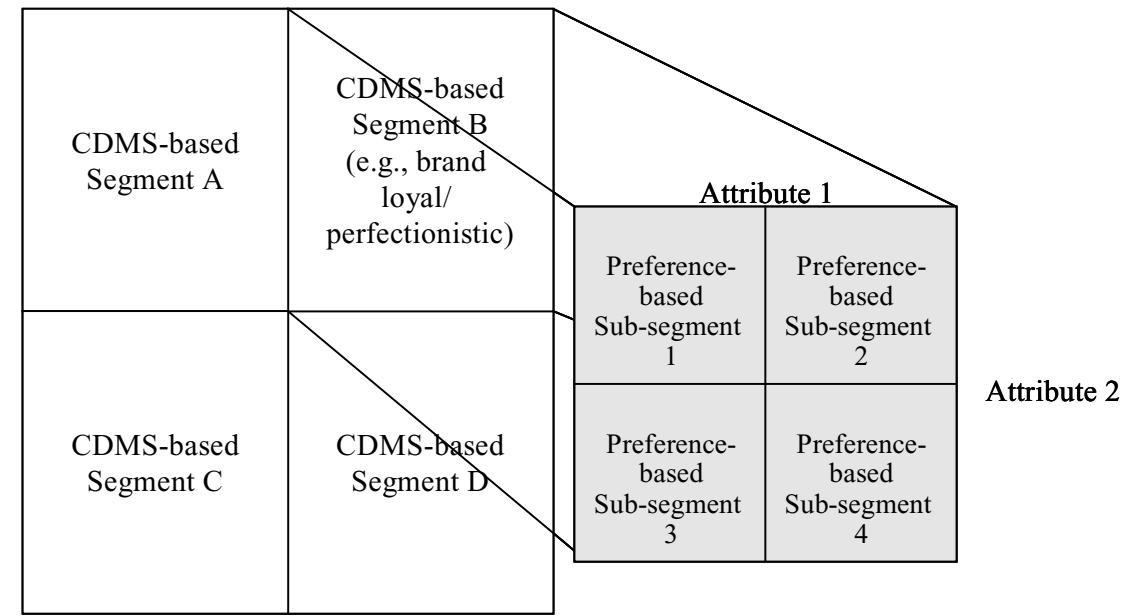

Note: $\mathrm{CDMS}=$ Consumer Decision-Making Style

Figure 1 Number of clusters and increase in heterogeneity

'impulsive' segment and if these segments are unwilling to pay the premium for the small display.

Thus far, only two studies exist that maintain that it is possible to discriminate between consumers on the basis of their decision-making style. One is an American study that revolves around the loyalty of catalogue item buyers, using a women-only sample. ${ }^{37}$ The other was carried out in the UK and used a student sample. ${ }^{38}$ Mitchell and Bates ${ }^{39}$ conclude that marketers could develop marketing strategies that appeal to decision-making style segments. As outlined earlier, however, the authors would argue that their understanding of the usefulness of decision-making style segments is a different one. More specifically, they doubt that marketers can effectively use decision-making segments at store and product level without considering another segmentation criterion.

The objectives of this study were to test the CSI's reliability and validity in Germany, examine the appropriateness of the CSI for market segmentation and to produce consumer decision-making segments.

\section{METHODOLOGY}

\section{The questionnaire}

A German version of Sproles and Kendall's 40-item CSI was developed. During translation due attention was paid to the issue of equivalence of meaning and in order to achieve comparability, back translation was conducted. A few items caused problems and were rephrased without altering their meaning. ${ }^{40}$ The questionnaire was face validated using exploratory interviews which revealed that some respondents were reluctant to answer certain items. ${ }^{41}$ The final German questionnaire included 38 of the 40 Sproles and Kendall items which were rated on a five-point agreedisagree scale (see Appendix 1 for items).

\section{The sample}

A sample of male and female shoppers (18 and older $)^{42}$ was drawn from those entering or leaving a shop in Lueneburg and Hamburg during July and August 1998. The interviews were carried out from Monday to Saturday at two different locations: one in front of a department 
Table 2: A comparison of the demographic profile of the sample and the German population

\begin{tabular}{llll}
\hline & $\begin{array}{l}\text { Sample demographic profile } \\
\%\end{array}$ & $\begin{array}{l}\text { Germany demographic profile } \\
\%\end{array}$ \\
\hline \multirow{2}{*}{ Age } & $18-31$ & 34 & 20 \\
& $32-44$ & 31 & 18 \\
& $45-57$ & 15 & 17 \\
Gender & $58+$ & 20 & 23 \\
\multirow{2}{*}{ Education } & Male & 44 & 49 \\
& Female & 56 & 51 \\
& More educated & 46 & 25 \\
& Less educated & 54 & 75 \\
\hline
\end{tabular}

*Subjects with 'only' a basic education (ie who completed lower or intermediate secondary school) formed the group of 'less-educated' consumers, while those with a higher education (ie A-levels [German 'Abitur'] and/or university degree) formed the group of 'more educated' consumers. Respondents with Abitur were considered more educated as they have spent 13 years at school (as opposed to people who went to lower or intermediate secondary school and have only done nine and ten years respectively)

store in the centre of Hamburg and the other on the premises of a supermarket in Lueneburg (within a seven-day and 17-day period respectively). Interviewers intercepted consumers leaving the department store or supermarket, which were typical in size and location of most other German cities.

Table 2 provides a description of the sample characteristics compared to the general population.

\section{Data analysis}

First, the authors examined the original eight-factor structure to see if it could be confirmed for German consumers. For testing purposes, confirmatory factor analysis (CFA) was instrumentalised, assigning the items according to the factor-loadings structure as described by Sproles and Kendall. The maximum likelihood algorithm of LISREL, version 8.12 was used for the calculation. Model identification, which is an indispensable condition for the interpretation of CFA results, was not reached, neither when considering all items from the original study nor a selection of three items per factor. Consequently, the appropriateness of the original eight-factor structure was questioned. To identify a more appropriate structure, a principal components analysis with Varimax rotation was performed. To identify the 'right' number of factors or decision-making styles dimensions, several alternative solutions were compared. Looking at the amount of explained variance, the eight, seven, six, and five-factor solutions were seen as most expressive. Solutions with a smaller number of factors explained an insufficient amount of variance of the data set, while solutions with more than eight factors could only marginally increase the explained variance. With the exception of the five-factor solution, the degree of explained variance was higher in all cases than the 46 per cent mentioned by Sproles and Kendall. Table 3 lists the relevant information for all four alternative solutions. If justifiable from looking at the loading structures, factors are named according to the titles used in the original study.

Following this, CFA were calculated for each of the four alternative solutions. Model identification was achieved for the eight, seven, and five-factor solutions, but not for the six-factor model. On the basis of a comparison of goodness-of-fit measures, the authors arrived at the conclusion that the seven-factor model best represented the data. The global fit was similar for all remaining models, while the local fit criteria indicate the seven-factor model to be clearly superior 
Table 3: Results of principal components analyses for four alternative solutions

\begin{tabular}{lcccc}
\hline & $\begin{array}{l}\text { 8-factor } \\
\text { model }\end{array}$ & $\begin{array}{l}\text { 7-factor } \\
\text { model }\end{array}$ & $\begin{array}{l}\text { 6-factor } \\
\text { model }\end{array}$ & $\begin{array}{l}\text { 5-factor } \\
\text { model }\end{array}$ \\
\hline $\begin{array}{l}\text { Explained variance } \\
\text { Eigenvalue of last extracted factor }\end{array}$ & $55.1 \%$ & $51.9 \%$ & $47.7 \%$ & $43.1 \%$ \\
& 1.28 & 1.58 & 1.74 & 2.01 \\
Cronbach's alpha & & & & \\
Perfectionism & 0.77 & 0.75 & 0.75 & 0.69 \\
Brand consciousness & 0.48 & 0.73 & 0.78 & 0.82 \\
Novelty-fashion consciousness & 0.71 & 0.71 & 0.69 & 0.65 \\
Recreational/hedonism & 0.42 & 0.65 & - & - \\
Price-value consciousness & - & - & - & 0.70 \\
Impulsiveness & 0.61 & 0.70 & 0.71 & 0.76 \\
Confused by overchoice & 0.76 & 0.75 & 0.76 & - \\
Habitual/brand-loyal & - & - & - & - \\
Factor A & 0.31 & - & - & - \\
Factor B & 0.46 & 0.53 & 0.53 & \\
\hline
\end{tabular}

to the alternative models (see Appendix 2). Here, only three of a total of 21 indicators have coefficients of determination smaller than 0.5 , and the average variance explained is higher than 0.5 for six out of seven factors.

In the German sample, more than a dozen out of 38 items loaded on factors other than those found for the US sample. The seven dimensions are labelled in line with those of Sproles and Kendall, when they reflect similar decision-making styles of German consumers and relate to: brand consciousness (dimension 1), perfectionism (dimension 2), recreational/hedonism (dimension 3), confused by overchoice (dimension 4), impulsiveness (dimension 5), novelty-fashion consciousness (dimension 6). The seven-factor model of decision-making style formed the starting point of an identification of distinct German consumer decision-making segments.

\section{Identifying German decision-making style segments}

To identify decision-making style segments of consumers, a hierarchical cluster analysis was performed. Cluster analysis is a well-established research method, and hierarchical (or linkage) clustering is the most popular way of distinguishing distinctive customer segments. In this study, cluster variables were used which served as indicators in the seven-factor solution of confirmatory factor analysis (see Appendix 1). To avoid conceivable error, which might result from an unequal number of items per factor, the items of each factor were aggregated (ie decision-making style dimensions) and the respective mean values used as input variables for clustering. Distances between the clusters were calculated with the Euclidean distance measure, and aggregation of clusters was performed with Ward's procedure. The latter is a commonly used algorithm which is known for its ability to produce valid solutions under conditions which are fulfilled in this study. As with exploratory factor analysis, cluster analysis does not deliver a 'true' solution, but leaves the decision about the appropriate number of clusters largely up to the researcher. To reflect the true structure of the data set, the elbow criterion was used to decide on the number of clusters. Figure 2 shows a plot with the number of clusters on the $\mathrm{x}$-axis and the increase in heterogeneity (the percentage) on the y-axis.

As Figure 2 illustrates, thresholds exists 


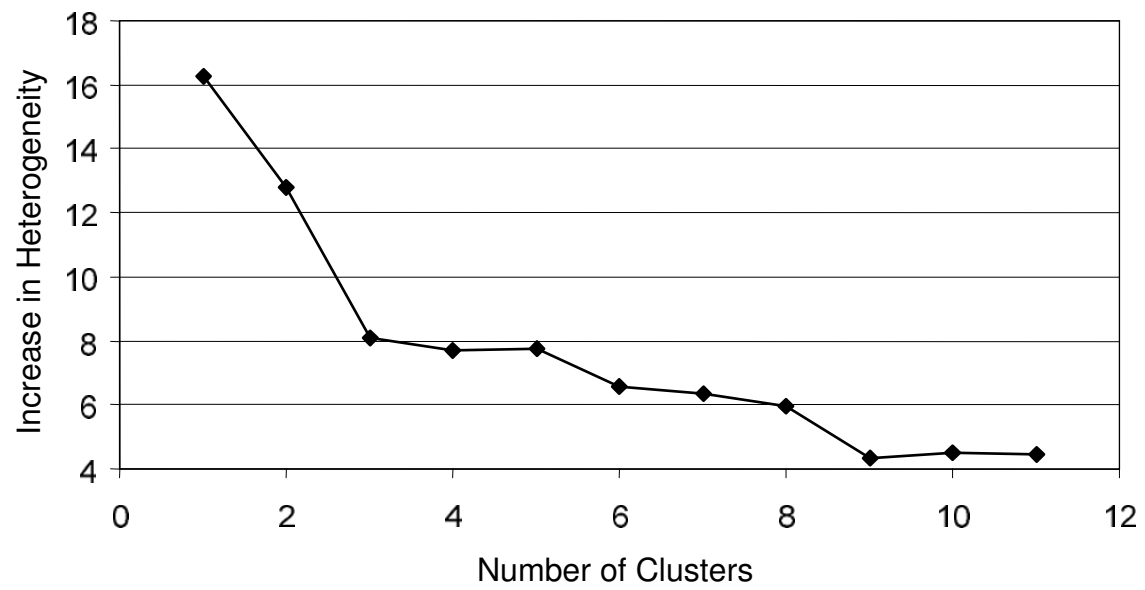

Figure 2 Number of clusters and increase in heterogeneity

at nine, six and three clusters, respectively, indicating that the 'true' number of clusters is nine, six or three. To be able to decide on the appropriateness of each of the three alternative solutions, an additional multiple discriminant analysis was performed for each of the three solutions. The hit rate (or proportion of customers correctly classified) is highest for the six-cluster solution according to the confusion matrices, with 90.5 per cent classified in the appropriate cluster, while the hit rates are slightly lower for the nine-cluster solution (89.7 per cent) and the three-cluster solution (85.7 per cent). Consequently, the six-cluster solution is seen to be the most adequate representation of existing German consumer decision-style segments. Figure 3 lists the mean values of the seven consumer decision-making dimensions (ie means of the respective aggregated cluster variables) for all six identified segments as well as the respective segment size. These results are now described briefly.

\section{RESULTS}

Segment 1 represents consumers whose buying behaviour is factual and value oriented. Only the dimension 'perfectionism' has a high average mean, while all the other dimensions have a low mean, particularly 'impulsiveness'. Interestingly, 'perfectionism' was strong in all six segments, indicating that Germans revere, demand (and deliver) high-quality products and that they are prepared to make an effort to find the 'right' product.

The demanding comparison shoppers in Segment 2 are the largest group, comprising 30 per cent of the sample. These consumers have high demands with regard to the products they purchase and enjoy searching for and choosing products. Their tendency to switch brands on a regular basis is neither the result of an emotional feeling nor cognitive confusion, but rather a conscious element of their shopping experience.

Segment 3 represents very impulsive consumers who tend to be rather indifferent with regard to brand and shopping experiences.

The buying decisions of consumers in Segment 4 are strongly emotionally dominated. These consumers, however, are 'hedonistic' and are likely to perceive 'confusion by overchoice'.

The fifth and smallest segment was 

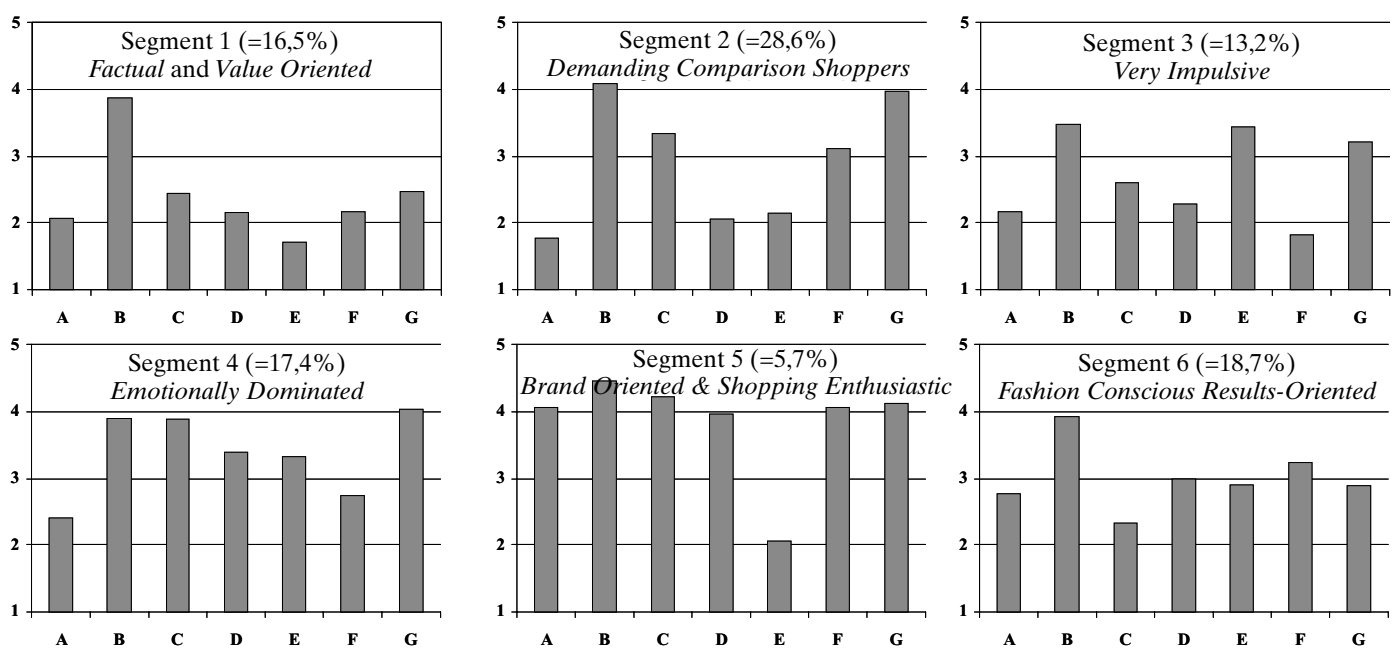

$\mathrm{A}=$ Brand Consciousness; $\mathrm{B}=$ Perfectionism; $\mathrm{C}=$ Recreational/Hedonism; $\mathrm{D}=$ Confused by Overchoice; $\mathrm{E}=$ Impulsiveness; $\mathrm{F}=$ Novelty-Fashion Consciousness; $\mathrm{G}=$ Variety Seeking

Figure 3 Mean values of cluster variables for the six decision-making styles segments

somewhat difficult to characterise because, with the exemption of one style, it has no outstanding or dominant style. Segment 5 represents

brand-oriented and shopping enthusiastic consumers. They have a keen interest in new products which causes them to alter their buying decisions, but they also show a proclivity to overchoice-confusion.

Fashion conscious result-oriented consumers in Segment 6 are less interested in the buying process itself than in the (branded) products they purchase.

These six segments have implications for marketing research and management and these will now be discussed.

Moreover, a new dimension was found that was labelled 'variety seeking', which has not previously been identified using the CSI. High scorers on this dimension are likely to switch brands, even if their current brands satisfy their needs. They may also switch brands to experience better alternatives or to increase stimulation by bringing something new into their lives.

\section{IMPLICATIONS}

The main goal of this study was to complement existing segmentation approaches by adding another segmentation criteria, namely a consumer's decision-making style.

Marketers could design products and/or communication strategies specifically to target these segments. Advertisements targeting consumers from the factual and value-oriented segment, for example, could focus on a product's key quality aspects rather than trying to convey an image or emotions.

Demanding comparison shoppers are likely to respond positively to stores offering a great assortment of branded high-quality products. When targeting the very impulsive segment of consumers, marketers could try to take advantage of their proclivity to purchase on impulse which can make it easier to persuade them to buy more than strictly necessary. ${ }^{43}$ These consumers could be targeted with in-store buying incentives (eg offering additional merchandise with the initial purchase) or attractively displayed eye-catching merchandise 
which is known to facilitate impulsive buying. There are also ways to capitalise on impulsive shoppers, even without a store visit taking place because impulsive buying can be instigated by television advertisements with phone numbers, online offers, etc. Emotionally dominated consumers like shopping and perhaps even view it as a way of self-realisation. These consumers are likely to go to shopping malls that cater for their fondness to browse different stores and where they can find recreation facilities such as restaurants, cinemas, health clubs or hairdressers. Consumers from this segment also have the opportunity to meet other people in a shopping mall.

Brand-oriented and shopping enthusiasts enjoy shopping, are eager to buy new products and brands, but tend to become confused from overchoice. These consumers are also likely to respond positively to up-market shopping malls. Such stores should not, however, offer too many (similar) products which can overload these consumers.

Fashion conscious results-oriented shoppers like new and fashionable products, but prefer a 'no-frills' approach to shopping. Factory outlet centres that offer branded products at reduced prices could cater for their needs because the shopping environment in such centres plays only a secondary role (eg merchandise sold out of cardboard boxes and not arranged on fancy shelves).

Finally, when looking at the results of this study and that of previous replications of the CSI it becomes apparent that certain dimensions (eg brand consciousness) emerge across countries while other dimensions (eg price-value consciousness) do not. This is indicative of the fact that the CSI has two components: one general to all cultures and the other specific to a specific culture. The implication of this for international marketing is that the general component could be used when targeting similar segments in different countries or when developing standardised products.

\section{CONCLUSION AND FUTURE RESEARCH}

The proposition of Sproles and Kendall's $^{44}$ eight-factor model was examined using a sample of 455 German consumers and performing exploratory as well as confirmatory factor analyses; a seven-dimensional structure was found to be the most appropriate representation of a German decision-making style. The dimensions are: brand consciousness, perfectionism, recreational/hedonism, confused by overchoice, impulsiveness, and novelty-fashion consciousness, and the previously unknown dimension, variety seeking. The validated seven dimensions were then used to create six distinct decision-making segments. The authors conclude that consumer decision-making styles can be used as the basis of segmenting consumers and it is likely that both specific needs and product and service preferences are associated with those segments. The authors believe that a segmentation based on decision-making styles could be even more appealing when used together with other segmentation criteria, eg demographic or psychographic segmentation. The results of such a multistage segmentation approach would be more precise, meaningful and consequently, of greater practical relevance.

The fact that the decision-making dimensions identified in a country subsequently determine decision-making style segments, suggests that further qualitative research is needed to ensure that all dimensions relevant to German consumers are considered in a German CSI. As noted, not all of the original 
dimensions could be confirmed in every country examined, which indicates that the current CSI seems unable to measure consumer decision-making characteristics effectively in all countries. Therefore, future German research should consider the possibility of adding additional dimensions known to be relevant to German consumers, which could lead to new decision-making style segments. Such dimensions could relate to the constructs of environmental consciousness, prestige-orientation or altruism that tends to lead to ethical buying decisions, dimensions which are known to exist in Germany.

Although decision-making dimensions were able to identify different segments, little consideration has yet been given to whether these segments are substantial, accessible, actionable, exhaustive, exclusive, responsive and stable, and therefore can be effectively used by marketers. In addition, further research is required to determine to what extent purchase behaviour differs at the product level, which would give more information on exactly what the identified segments look for in products to satisfy their differing needs.

\section{Acknowledgement}

This paper is based on one which received the Best Paper Award in the Global Marketing SIG Track at the 2001 AMA Marketing Educators' Conference, Washington DC. The authors thank the participants of the Global Marketing SIG Track for their comments and suggestions. The authors also greatly appreciate the comments and critiques of two anonymous reviewers of this journal.

\section{References:}

1 Sproles, G. B. and Kendall, E. (1986) 'A methodology for profiling consumers' decision-making styles', Journal of Consumer Affairs, Vol. 20, No. 2, pp. 267-279.

2 Lastovicka, J. L. and Joachimsthaler, E. A. (1988) 'Improving the detection of personality-behavior relationships in consumer research', Journal of Consumer Research, Vol. 14, pp. 583-587, March.

3 Lutz, R. J. (1991) 'The role of attitude theory in marketing', in 'Perspectives in consumer behavior',
Kassarjian, H. H. and Robertson, T. S. (eds) 4th ed., Prentice Hall, Englewood Cliffs, NJ, pp. 317-339.

4 Anderson, W. T. and Golden, L. L. (1984) 'Lifestyle and psychographics: A critical review and recommendation', in 'Advances in consumer research', Kinnear, T. C. (ed.), Vol. 11, Association for Consumer Research, Provo, UT, pp. 405-411.

5 Stone, G. P. (1954) 'City shoppers and urban identification: Observations on the social psychology of city life', American Journal of Sociology, Vol. 60, pp. 36-45, July.

6 Darden, W. R. and Reynolds, F. D. (1971) 'Shopping orientation and product usage rates', Journal of Marketing Research, Vol. 8, pp. 505-508, November.

7 Darden, W. R. and Ashton, D. (1974/75) 'Psychographic profiles of patronage preference groups', Journal of Retailing, Vol. 50, No. 4, pp. 99-112.

8 Ibid.

9 Thorelli, H. B., Becker, H. and Engledow, J. (1975) 'The information seekers: An international study of consumer information and advertising image', Ballinger, Cambridge.

10 Lichtenstein, D. R., Ridgway, N. M. and Netemeyer, R. G. (1993) 'Price perceptions and consumer shopping behavior: A field study', Journal of Marketing Research, Vol. 30, pp. 234-245, May.

11 Menon, S. and Kahn, B. E. (1995) 'The impact of context on variety seeking in product choices', Journal of Consumer Research, Vol. 22, pp. 285-295, December.

12 Jacoby, J. and Chestnut, R. W. (1978) 'Brand loyalty: Measurement and management', Wiley, New York, NY.

13 Schmalen, H. (1994) 'Das hybride Kaufverhalten und seine Konsequenzen für den Handel' [Hybrid Consumer Behavior and Its Consequences for Retailing], Zeitschrift für Betriebswirtschaft, Vol. 64, No. 10, pp. 1221-1240.

14 Sproles and Kendall (1986) op. cit.

15 Ibid.

16 McDonald, W. J. (1993) 'The roles of demographics, purchase histories and shopper decision making styles in predicting consumer catalog loyalty', Journal of Direct Marketing, Vol. 7, No. 3, pp. 55-65. Mitchell, V.-W. and Bates, L. (1998) 'UK consumer decision-making styles', Journal of Marketing Management, Vol. 14, Nos 1-3, pp. 199-225.

17 Sproles and Kendall (1986, p. 268)

18 Sproles and Kendall (1986, p. 270) do not rule out the existence of other dimensions: 'We acknowledge that other characteristics might be equally valuable for specific applications, but the characteristics chosen are among the most frequently discussed in consumer literature.'

19 Sproles and Kendall (1986) op. cit.

20 Ibid.

21 These two dimensions had a Cronbach alpha less than 0.50 and the dimensions confused by overchoice and habitual/brand-loyal alphas of below 0.60 , indicating that they were not very reliable. 
Reliability is the random error component of a measurement instrument. A measurement is reliable if it reflects mostly true score, relative to the error. Cronbach alpha is a measure of squared correlation between observed scores and true scores (ie reliability is measured in terms of the ratio of true score variance to observed score variance).

22 Sproles and Kendall (1986, p. 277) op. cit.

23 Hafstrom, J. L., Chae, J. S. and Chung, Y. S. (1992) 'Consumer decision-making styles: Comparison between United States and Korean young consumers', Journal of Consumer Affairs, Vol. 26, No. 1, pp. 146-158.

24 Durvasula, S., Lysonski, S. and Andrews, J. C. (1993) 'Cross-cultural generalizability of a scale for profiling consumers' decision-making styles', Journal of Consumer Affairs, Vol. 27, No. 1, pp. 55-65.

25 Lysonski, S., Durvasula, S. and Zotos, Y. (1996) 'Consumer decision-making styles: A multi-country investigation', European Journal of Marketing, Vol. 30 No. 12, pp. 10-21.

26 Mitchell and Bates (1998) op. cit. Ref. 16.

27 Fan, J. X. and Xiao, J. J. (1998) 'Consumer decision-making styles of young-adult Chinese', Journal of Consumer Affairs, Vol. 32, No. 2, pp. 275-293.

28 Replications are widely considered an integral part of scientific work. On the necessity of replications see the special issue of the Journal of Business Research, Vol. 48, No. 1.

29 Hafstrom et al. (1992) op. cit.

30 Through inclusion of some items by Sproles (1985) the South Korean questionnaire consisted of 44 items instead of 40.

31 Lysonski et al. (1996) op. cit.

32 Fan and Xiao (1998) op. cit.

33 Frank, R. E., Massy, W. F. and Wind, Y. (1972) 'Market segmentation', Prentice-Hall, Englewood Cliffs, NJ.

34 Hennig-Thurau, T. and Hansen, U. (eds) (2000) 'Relationship marketing: Gaining competitive advantage through customer satisfaction and customer retention', Springer, Berlin.

35 It is likely that in many cases decision-making segmentation can be used as a preliminary or segmentation approach. For example, if a retailer decided to go into e-commerce and wanted to know which products are most suitable for an online shop, a demographic segmentation could be conducted first (eg by gender and income), followed by one using decision-making styles (which are associated with product preferences). A mainly female clientele would clearly allow the retailer to narrow down the potential assortment size, but also knowing that a sizeable number of customers are 'novelty-fashion seeking' would make it even easier to find the optimal online assortment. The retailers could also opt to use both segmentation approaches in reverse order.

36 Engel, J. F., Blackwell, R. D. and Miniard, P. W. (1995) 'Consumer behavior', 8th edition, The Dryden Press, Fort Worth.

37 McDonald (1993) op. cit.

38 Mitchell and Bates (1998) op. cit.

39 Ibid.

40 For example, the word 'confused' in the German questionnaire was replaced by 'durcheinander' (mixed up), which is a more neutral word because 'confusion' (German: 'Konfusion', 'Verwirrtheit') has unfavourable connotations in Germany.

41 For example, problems emerged as to item 13 ('I prefer buying the best selling brands'). Respondents felt unable to know which brands sell best because only in very few product categories (eg CDs, videos) do consumers know which products sell best through chart ratings.

42 In Germany, at the age of 18 people gain full legal status, which entitles them to buy any (legal) product they desire.

43 Rook, D. W. (1987) 'The buying impulse', Journal of Consumer Research, Vol. 14, pp. 189-199.

44 Sproles and Kendall (1986) op. cit.

45 CFA was performed for each factor separately. Items that lead to a factor's deterioration were excluded from the analysis and labelled (n.c.; not considered) in the table. In the simultaneous analysis those items were excluded that had a coefficient of determination (COD) below 0.4 . 
Appendix 1: Items and goodness-of-fit measures of principal components and confirmatory factor analysis

\begin{tabular}{|c|c|c|c|}
\hline Items & $\begin{array}{l}\text { Factor } \\
\text { loadings } \\
\text { (of PCA) }\end{array}$ & $\begin{array}{l}\text { Coefficients of } \\
\text { determination } \\
\text { (of CFA) }\end{array}$ & Means \\
\hline Factor 1: Brand consciousness & $\begin{array}{l}5.44 \\
\text { (Eigenvalue) }\end{array}$ & $\begin{array}{l}0.71 \text { (Average } \\
\text { variance } \\
\text { explained) }\end{array}$ & \\
\hline $\begin{array}{l}\text { The more expensive brands are usually } \\
\text { my choice }\end{array}$ & 0.71 & 0.79 & 2.26 \\
\hline $\begin{array}{l}\text { The well-known national brands are } \\
\text { best for me }\end{array}$ & 0.70 & 0.65 & 2.44 \\
\hline $\begin{array}{l}\text { The higher the price of the product, the } \\
\text { better the quality }\end{array}$ & 0.69 & 0.69 & 2.20 \\
\hline $\begin{array}{l}\text { I look carefully to find the best value for } \\
\text { the money }\end{array}$ & -0.50 & n.c. & 1.95 \\
\hline $\begin{array}{l}\text { Nice department and speciality stores } \\
\text { offer me the best products }\end{array}$ & 0.45 & n.c. & 2.98 \\
\hline $\begin{array}{l}\text { The most advertised brands are usually } \\
\text { very good choices }\end{array}$ & 0.43 & n.c. & 2.52 \\
\hline $\begin{array}{l}\text { A product doesn't have to be perfect, or } \\
\text { the best, to satisfy me }\end{array}$ & -0.41 & n.c. & 2.83 \\
\hline Factor 2: Perfectionism & 3.48 & 0.53 & \\
\hline $\begin{array}{l}\text { In general, I usually try to buy the best } \\
\text { overall quality }\end{array}$ & 0.78 & 0.67 & 4.04 \\
\hline $\begin{array}{l}\text { When it comes to purchasing products, I } \\
\text { try to get the best, or perfect choice }\end{array}$ & 0.77 & 0.58 & 3.67 \\
\hline $\begin{array}{l}\text { Getting good quality is very important to } \\
\text { me }\end{array}$ & 0.67 & 0.47 & 4.28 \\
\hline $\begin{array}{l}\text { My standards and expectations for } \\
\text { products I buy are very high }\end{array}$ & 0.60 & 0.41 & 3.74 \\
\hline $\begin{array}{l}\text { I make special effort to choose the very } \\
\text { best quality products }\end{array}$ & 0.56 & n.c. & 2.2 \\
\hline Factor 3: Recreational/hedonism & 3.11 & 0.66 & \\
\hline $\begin{array}{l}\text { Shopping is not a pleasant activity to } \\
\text { me }\end{array}$ & -0.70 & 0.47 & 3.32 \\
\hline $\begin{array}{l}\text { Going shopping is one of the enjoyable } \\
\text { activities of my life }\end{array}$ & 0.67 & 0.85 & 2.78 \\
\hline I make my shopping trips fast & -0.55 & n.c. & 2.57 \\
\hline $\begin{array}{l}\text { Shopping in many stores wastes my } \\
\text { time }\end{array}$ & -0.51 & n.c. & 3.51 \\
\hline $\begin{array}{l}\text { It's fun to buy something new and } \\
\text { exciting }\end{array}$ & 0.47 & n.c. & 3.31 \\
\hline $\begin{array}{l}\text { I shop quickly, buying the first product } \\
\text { or brand I find that seems good } \\
\text { enough }\end{array}$ & -0.44 & n.c. & 3.37 \\
\hline $\begin{array}{l}\text { I really don't give my purchases much } \\
\text { thought or care }\end{array}$ & -0.44 & n.c. & 3.60 \\
\hline $\begin{array}{l}\text { To get variety, I shop in different stores } \\
\text { and choose different brands }\end{array}$ & 0.42 & n.c. & 3.58 \\
\hline Factor 4: Confused by overchoice & 2.34 & 0.57 & \\
\hline $\begin{array}{l}\text { The more I learn about products, the } \\
\text { harder it seems to choose the best }\end{array}$ & 0.74 & 0.70 & 2.86 \\
\hline $\begin{array}{l}\text { All the information I get on different } \\
\text { products confuses me }\end{array}$ & 0.71 & 0.59 & 2.33 \\
\hline $\begin{array}{l}\text { Sometimes it's hard to choose which } \\
\text { stores to shop }\end{array}$ & 0.71 & 0.43 & 2.65 \\
\hline $\begin{array}{l}\text { There are so many brands th choose } \\
\text { from that I often feel confused }\end{array}$ & 0.59 & 0.32 & 2.62 \\
\hline Factor 5: Impulsiveness & 2.01 & 0.52 & \\
\hline $\begin{array}{l}\text { Often I make careless purchases I later } \\
\text { wish I had not }\end{array}$ & 0.72 & 0.67 & 2.33 \\
\hline I am impulsive when purchasing & 0.71 & 0.38 & 2.77 \\
\hline $\begin{array}{l}\text { I should plan my shopping more carefully } \\
\text { than I do }\end{array}$ & 0.67 & 0.50 & 2.64 \\
\hline I carefully watch how much I spend & -0.60 & n.c. & 2.46 \\
\hline $\begin{array}{l}\text { I take the time to shop carefully for the } \\
\text { best buys }\end{array}$ & -0.53 & n.c. & 2.77 \\
\hline
\end{tabular}


Appendix 1: continued

\begin{tabular}{|c|c|c|c|}
\hline Items & $\begin{array}{l}\text { Factor } \\
\text { loadings } \\
\text { (of PCA) }\end{array}$ & $\begin{array}{l}\text { Coefficients of } \\
\text { determination } \\
\text { (of CFA) }\end{array}$ & Means \\
\hline $\begin{array}{l}\text { Factor 6: Novelty-fashion } \\
\text { consciousness }\end{array}$ & 1.74 & 0.58 & \\
\hline $\begin{array}{l}\text { I keep my wardrobe up-to-date with the } \\
\text { changing fashions }\end{array}$ & 0.84 & 0.77 & 2.61 \\
\hline $\begin{array}{l}\text { Fashionable, attractive styling is very } \\
\text { important to me }\end{array}$ & 0.69 & 0.36 & 3.32 \\
\hline $\begin{array}{l}\text { I usually have one or more outfits of the } \\
\text { very newest style }\end{array}$ & 0.68 & 0.61 & 2.47 \\
\hline $\begin{array}{l}\text { I enjoy shopping just for the fun of it } \\
\text { Factor 7: Variety seeking }\end{array}$ & $\begin{array}{l}0.40 \\
1.58\end{array}$ & $\begin{array}{l}\text { n.c. } \\
0.48\end{array}$ & 2.29 \\
\hline I change brands I buy regularly & 0.70 & n.c. & 2.59 \\
\hline $\begin{array}{l}\text { Once I find a product or brand I like, I } \\
\text { stick with it }\end{array}$ & -0.54 & n.c. & 3.31 \\
\hline $\begin{array}{l}\text { It's fun to buy something new and } \\
\text { exciting }\end{array}$ & 0.49 & 0.53 & 3.69 \\
\hline $\begin{array}{l}\text { To get variety, I shop in different stores } \\
\text { and choose different brands }\end{array}$ & 0.45 & 0.43 & 3.58 \\
\hline $\begin{array}{l}\text { Nice department and speciality stores } \\
\text { offer me the best products }\end{array}$ & -0.44 & n.c. & 2.98 \\
\hline
\end{tabular}

n.c. $=$ not considered in the analysis ${ }^{45}$

Appendix 2: Global and local goodness-of-fit measures from CFA for three alternative models

\begin{tabular}{llll}
\hline Global goodness of fit & 8-factor model & 7-factor model & 5-factor model \\
\hline GFI & 0.808 & 0.826 & 0.830 \\
AGFI & 0.742 & 0.761 & 0.772 \\
RMR & 0.084 & 0.079 & 0.083 \\
RMSEA & 0.113 & 0.112 & 0.114 \\
CFI & 0.730 & 0.778 & 0.761 \\
\hline Local goodness of fit & 8-factor model & 7-factor model & 5-factor model \\
\hline Coefficients of & 6 out of 24 items & 3 out of 21 items & 7 out of 19 items \\
$\quad$ determination (COD) for & with COD $<0.4$ & with COD $<0.4$ & with COD $<0.4$ \\
$\quad$ included items & 2 factors with & 1 factor with AVE & 2 factors with \\
Average variances & AVE $<0.5$ (factor & $<0.5$ (factor & AVE $<0.5$ \\
$\quad$ ('perfectionistic' $=0.48 ;$ \\
included factors & $\mathrm{A}=0.35 ;$ factor & $\mathrm{B}=0.48$ ) & 'novelty-fashion \\
& $\mathrm{B}=0.48$ ) & & consciousness' $=0.36$ \\
\hline
\end{tabular}

